\title{
PENINGKATAN KEMAMPUAN MENYELESAIKAN SOAL CERITA KONEKSI MATEMATIK MELALUI MODEL PEMBELAJARAN LEARNING CYCLE 5E
}

\author{
Herton$^{1}$, Muh. Rusydi Rasyid ${ }^{2}$, Sri Sulasteri ${ }^{3}$ \\ 1,2,3Universitas Islam Negeri Alauddin Makassar \\ 1,2,3Kampus II: Jl. H.M. Yasin Limpo No. 36 Samata-Gowa \\ Email: herton@gmail.com¹, rusydi.rasyid@uin-alauddin.ac.id², \\ sri.sulasteri@uin-alauddin.ac.id ${ }^{3}$
}

\begin{abstract}
Abstrak:
Penelitian ini bertujuan untuk meningkatkan kemampuan menyelesaikan soal cerita koneksi matematik siswa kelas VIII 1 MTs Negeri Model Makassar. Jenis Penelitian ini adalah penelitian tindakan kelas (Classroom Action Research), yang terdiri dari 4 tahap yaitu perencanaan, pelaksanan, pengamatan, dan refleksi. Tindakan dilaksanakan dalam 2 siklus dengan masing-masing siklus terdiri dari 2 pertemuan. Pengumpulan data dilakukan dengan cara observasi, dokumentasi, dan tes kemampuan menyelesaikan soal cerita koneksi matematik. Subyek penelitian sebanyak 40 orang siswa kelas VIII-1 MTsN Model Makassar yaitu siswa perempuan berjumlah 19 dan siswa laki-laki 21 orang, serta objek penelitian yaitu kemampuan menyelesaikan soal cerita koneksi matematik. Berdasarkan hasil analisis data, didapatkan hasil; (1) keterlaksanaan model pembelajaran berdasarkan lembar observasi yaitu siklus I terdiri dari dua pertemuan kegiatan siswa berturut-turut yaitu $60 \%$ dan $80 \%$ dan untuk kegiatan guru berturut-turut adalah $80 \%$ dan $90 \%$, serta siklus II terdiri dari dua pertemuan untuk kegiatan siswa berturut-turut adalah $90 \%$ dan 100\% serta kegiatan guru berturut-turut adalah 100\% dan 100\%; (2) kemampuan menyelesaikan soal cerita koneksi matematik yang berhasil dicapai siswa dengan menggunakan model pembelajaran Learning Cycle pada siklus I untuk indikator 1, indikator 2 dan indikator 3 berturutturut ada sebesar 92,5\%,67,5\%, dan 20\%, serta siklus II banyak siswa yang berhasil mengalami peningkatan kemampuan menyelesaikan soal cerita koneksi matematik yaitu indikator 1, indikator 2, dan indikator 3 berturut-turut ada sebesar 97,5\%, $92,5 \%$, dan $80 \%$.
\end{abstract}

\begin{abstract}
:
The study aimed at improving the ability to solve the mathematical connection story problems at class VIII 1 students of MTs Negeri Model Makassar. The study was a classroom action research consisting of 4 stages of planning, implementation, observation, and reflection. The actions were carried out in 2 cycles with each cycle consisting of 2 meetings. The data collection was done by observing, documenting, and testing the ability in solving the mathematical connection story problems. The subjects of the study were 40 students of class VIII-1 MTsN Model Makassar namely 19 female and 21 male students. The object
\end{abstract}


of the research was the ability to solve the mathematical connection story problems. Based on the results of the data analysis, it was found out the results: (1) the implementation of the learning model based on the observation sheet in cycle I consisted of two consecutive student activity meetings of $60 \%$ and $80 \%$ and for teacher activity were $80 \%$ and 90 , and cycle II consisted of two meetings for the student's successive activities were $90 \%$ and $100 \%$ as well as teacher activity in a row is $100 \%$ and $100 \%$; (2) the ability to solve the mathematical connection story problems of the students using Learning Cycle model in cycle I for indicator 1, indicator 2 and indicator 3 respectively there are $92,5 \%, 67,5 \%$, and $20 \%$, and cycle II many students who succeeded in improving the ability to solve the problem of mathematical connection for indicator 1, indicator 2, and indicator 3 there were $97,5 \%, 92,5 \%$, and $80 \%$ respectively.

Kata kunci: Soal Cerita, Koneksi Matematik, Learning Cycle “5E”

MATEMATIKA merupakan pelajaran yang sangat penting baik di lingkungan sekolah, keluarga, masyarakat, bahkan sampai ajal menjemput. Pembelajaran matematika bukan hanya mengetahui cara berhitung, namun harus mengetahui tentang konsep matematika yang berkaitan dengan ide abstrak. Oleh karena itu diperlukan sebuah model atau metode dalam menyampaikan materi matematika yang abstrak menjadi konkret, hal ini didukung oleh konsep pembelajaran bermakna dari Ausebel (Zaerani, Mardhiah, \& Suharti, 2017), sehingga dalam mengajar matematika dapat dijelaskan melalui contoh-contoh dalam kehidupan sehari-hari siswa, dengan harapan siswa akan lebih mengerti (Angriani, Bernard, Nur, \& Nurjawahirah, 2016). Masalah yang dihadapi dalam belajar matematika biasanya dinyatakan dalam bentuk soal cerita, baik tertulis maupun lisan, maka yang dibutuhkan adalah koneksi matematik siswa. Soal cerita yang terdapat dalam matematika merupakan persoalan-persoalan yang terkait dengan permasalahanpermasalahan dalam kehidupan sehari-hari yang dapat dicari penyelesaiannya dengan menggunakan kalimat matematika. Koneksi matematik itu sendiri dapat diartikan sebagai keterkaitan secara internal (hubungan dengan matematika itu sendiri) dan eksternal (hubungan matematika dengan kehidupan sehari-hari). Pengoptimalan kemampuan menyelesaikan soal cerita koneksi matematik siswa, solusinya adalah dengan menggunakan pembelajaran kolaboratif dengan teknik "5E". Teknik "5E" sering dikenal dengan Learning Cycle (siklus mengajar). Menurut (Noviantari, 2015), Learning Cycle berkembang menjadi 5 (lima) tahap yang terdiri atas engagement (melibatkan siswa dalam meningkatkan minat siswa), exploration (memberikan kesempatan kepada mereka untuk membangun pemahamannya sendiri), explanation (siswa diberi kesempatan untuk mengomunikasikan apa yang telah dipelajarinya), elaboration (siswa diberi kesempatan untuk menerapkan pengetahuan barunya), serta evaluation (siswa maupun guru menilai sejauh mana terjadi pembelajaran dan pemahaman). 
Menurut Raharjo dan Astuti, soal cerita merupakan persoalan-persoalan yang terkait dengan permasalahan-permasalahan dalam kehidupan sehari-hari yang dapat dicari penyelesaiannya dengan menggunakan kalimat matematika (Khasana, 2015:3). Koneksi matematik merupakan keterkaitan secara internal (hubungan dengan matematika itu sendiri) dan eksternal (hubungan matematika dengan kehidupan sehari-hari), tanpa kemampuan koneksi matematik siswa wajib mengingat terlalu banyak konsep dan prosedur matematika (Putra, 2015:146).

Model pembelajaran LC pertama kali diperkenalkan oleh Robert Karplus dalam science Curriculum Improvement Study/SCIS pada program pembelajaran sains untuk kels 6. Awalnya hanya terdiri dari 3 (tiga) tahap yakni eksplorasi (ekploration), penciptaan (invention), dan penemuan (discoveri). Model ini kemudian dikembangkan oleh suatu tim yang dipimpin oleh Robert Bybee (1997) dari The Biological Science Curriculum Study (BSCS) (Warsono, 2014:100). Model 5E memiliki lima fase, yaitu engage, explore, explain, elaborate, dan evaluate. Pada tahap engage, guru melibatkan siswa dalam masalah baru dengan menggunakan kegiatan pendek atau pertanyaan untuk menumbuhkan rasa ingin tahu mereka dan menggali pengetahuan awal mereka. Tahap eksplorasi mengarahkan siswa tidak hanya melakukan kegiatan, seperti kegiatan praktikum, diskusi kelompok, tetapi juga mengeksplorasi pertanyaan-pertanyaan dan menerapkan pengetahuan awal mereka dalam suatu penyelidikan. Pada fase explain, guru memiliki kesempatan untuk langsung memperkenalkan konsep, proses, atau keterampilan sehingga siswa dapat mengecek apakah pemahaman mereka tentang suatu pengetahuan itu adalah pengetahuan yang benar atau salah (Rahayu, Mulyani, \& Miswadi, 2012: 84). Penelitian ini dikatakan penting karena dalam faktanya, siswa kesulitan dalam memahami bahasa soal dan sulit menghubungkan materi pada saat itu dengan materi sebelumnya yang terkait. Pengoptimalan kemampuan menyelesaikan soal cerita koneksi matematik siswa khususnya kelas VIII 1 MTsN Model Makassar dengan menggunakan pembelajaran kolaboratif dengan teknik " $5 \mathrm{E}$ ".

\section{METODE PENELITIAN}

Penelitian yang digunakan adalah penelitian tindakan kelas (classroom action research) menurut model Kemmis dan Mc. Taggart dengan tahapan-tahapan pelaksanaan meliputi: perencanaan, pelaksanaan, tindakan, refleksi, dan evaluasi secara berulang (Ermalinda, 2014:30). Prosedur penelitan sebagai berikut 


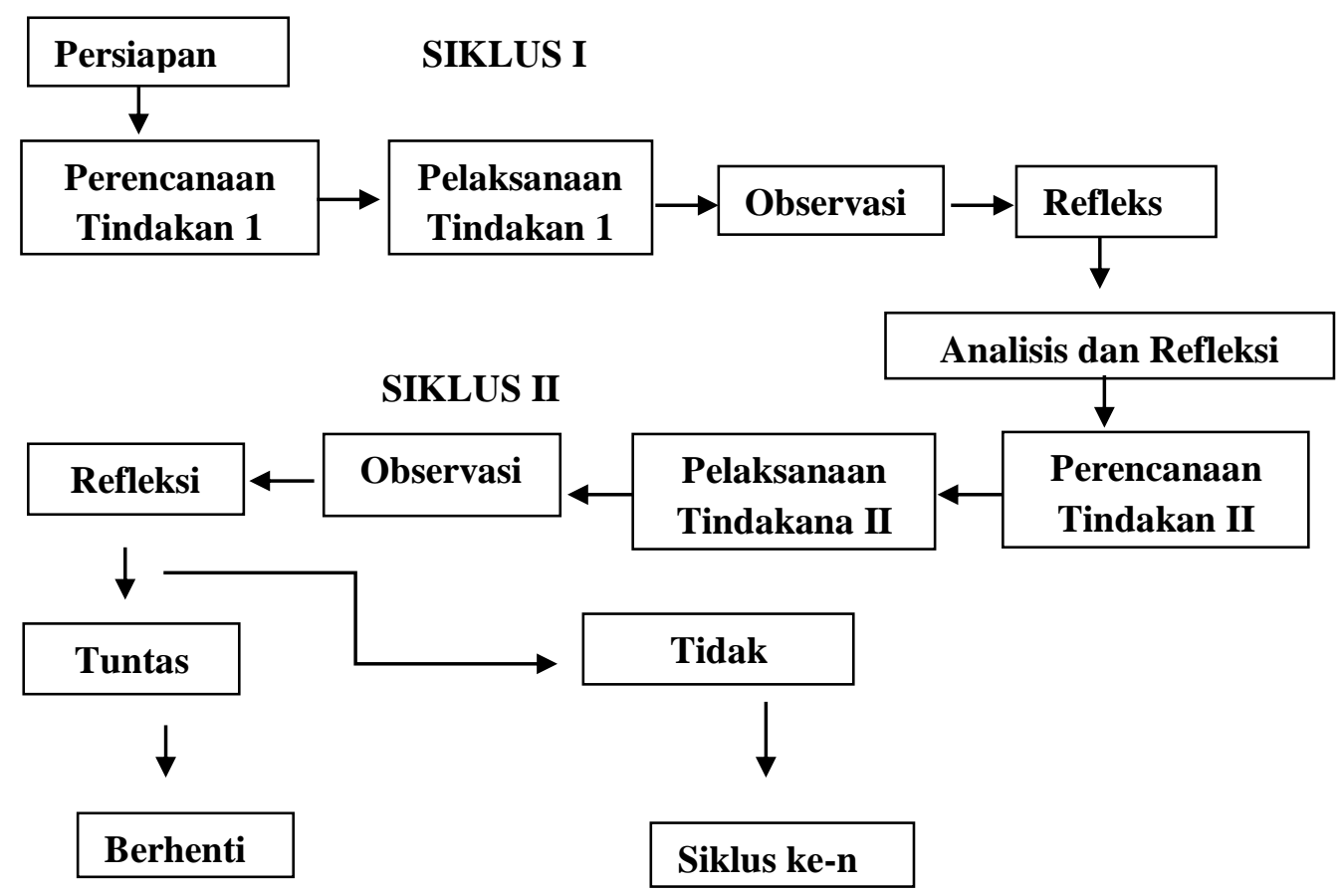

Gambar 1: Prosedur Penelitian

Subyek penelitian dalam penelitian ini adalah 40 orang siswa kelas VIII-1 MTsN Model Makassar, dengan siswa perempuan berjumlah 19 dan siswa laki-laki 21 orang. Objek dalam penelitian ini adalah kemampuan menyelesaikan soal cerita koneksi matematik. Indikator keberhasilan pada penelitian ini adalah pelaksanaan model pembelajaran Learning Cycle 5E dilihat dari kegiatan siswa dan kegiatan guru dapat mencapai keberhasilan $80 \%$ dan tingkat kemampuan siswa menyelesaikan soal cerita koneksi matematik mencapai $80 \%$.

\section{HASIL PENELITIAN DAN PEMBAHASAN}

Analisis tes kemampuan menyelesaikan soal cerita koneksi matematik dan analisis dari masing-masing pelaksanaan tindakan pada setiap siklus dapat diuraikan sebagai berikut:

\section{Hasil Analisis Siklus I}

\section{Hasil Analisis Kuantitatif}

Data kemampuan menyelesaikan soal cerita koneksi matematik siklus I diperoleh melalui pemberian tes soal cerita koneksi matematik materi luas permukaan kubus setelah pemberian materi. Berdasarkan skor kemampuan menyelesaikan soal cerita koneksi matematik siswa MTS Negeri Model Makassar pada siklus I diperoleh bahwa rata-rata skor kemampuan koneksi dalam menyelesaikan soal cerita koneksi matematik peserta didik kelas VIII 1 MTs Negeri 1 Makassar diperoleh skor rata-rata kemampuan menyelesaikan soal cerita koneksi 
matematik peserta didik adalah 80 dari skor maksimun ideal yang dapat dicapai yaitu 100, dengan skor tertinggi yang dicapai adalah 80 dan skor terendah adalah 50.

Berdasarkan deskripsi pelaksanaan penelitian tindakan kelas siklus I, terdapat beberapa masalah pada fase yang terdapat pada model pembelajaran Learning Cycle “5E", masalah terdapat pada fase exploration, fase explanation, dan fase evaluation. Pada fase exploration, siswa masih kesulitan dalam menuliskan diketahui, ditanyakan, membuat model matematika dari suatu masalah kehidupan sehari-hari, menuliskan konsep apa saja yang digunakan siswa dalam menjawab soal, dan menuliskan hubungan antar konsep dalam menjawab soal.

Pada fase explanation, masalah yang ditemui adalah siswa masih malu-malu dan takut salah dalam mempresentasikan hasil diskusi kelompok, masih ada beberapa siswa yang mengobrol dan sibuk sendiri selama presentasi berlangsung. Pada fase evaluation, masalah yang ditemui adalah kurangnya waktu dalam mengkoreksi jawaban bersama-sama, sehingga fase evaluation dilanjutkan setelah pelajaran berakhir, dan guru memberikan simpulan setelah pengkoreksian tersebut selesai. Hal ini terjadi selama 2 kali pertemuan.

Berikut ini adalah pengkategorian kemampuan menyelesaikan soal cerita koneksi matematik:

a. Indikator 1 (Menuliskan masalah kehidupan sehari-hari dalam bentuk model matematika) kategori sangat kurang, kurang, cukup, baik dan sangat baik berturut-turut adalah 2 orang, 1 orang, 23 orang, 6 orang dan 8 orang.

b. Indikator 2 (Menuliskan konsep matematika yang mendasari jawaban ) kategori sangat kurang, kurang, cukup, baik dan sangat baik berturut-turut adalah 10 orang, 3 orang, 21 orang, 6 orang dan 0 orang.

c. Indikator 3 (Menuliskan hubungan antar obyek dan konsep matematika) kategori sangat kurang, kurang, cukup, baik dan sangat baik berturut-turut adalah 32 orang, 0 orang, 6 orang, 2 orang dan 0 orang.

Peningkatan kemampuan menyelesaikan soal cerita koneksi matematik di hitung dari jumlah pengkategorian cukup, baik, dan sangat baik. Hasil dari siklus I untuk tes kemampuan menyelesaikan soal cerita koneksi matematik sampai akhir siklus I untuk indikator 1, indikator 2, dan indikator 3, berturut-turut ada sebesar $92,5 \%, 67,5 \%$, dan $20 \%$.

\section{Hasil Analisis Kualitatif}

Dalam observasi keterlaksanaan model pembelajaran Learning Cycle siklus 1 untuk kegiatan siswa pada pertemuan 1 dan pertemuan 2 berturut-turut presentasinya adalah $60 \%$ dan $80 \%$. Hal ini berarti bahwa keterlaksanaan model pembelajaran Learning Cycle $5 E$ pada pertemuan 1 belum mencapai indikator keberhasilan dan pada pertemuan 2 sudah mencapai indikator keberhasilan.

Hasil observasi kegiatan siswa model pembelajaran learning cycle 5E kelas VIII 1 MTs Negeri Model Makassar pada Siklus I menunjukkan bahwa dalam observasi keterlaksanaan model pembelajaran Learning Cycle siklus 1 untuk kegiatan guru pada 
pertemuan 1 dan pertemuan 2 berturut-turut presentasinya adalah 80\% dan 90\%. Oleh karena itu keterlaksanaan model pembelajaran Learning Cycle 5E berhasil. Dapat dikatakan berhasil karena kegiatan guru pada pertemuan 1 dan pertemuan 2 mencapai indikator keberhasilan yaitu $80 \%$.

\section{Hasil Analisis Siklus II}

\section{Hasil Analisi Kuantitatif}

Data kemampuan menyelesaikan soal cerita koneksi matematik siklus I diperoleh melalui pemberian tes soal cerita koneksi matematik materi luas permukaan kubus setelah pemberian materi. rata-rata skor kemampuan koneksi menyelesaikan soal cerita koneksi matematik peserta didik kelas VIII 1 MTs Negeri Model Makassar diperoleh skor rata-rata kemampuan menyelesaikan soal cerita koneksi matematik peserta didik adalah 80 dari skor maksimun ideal yang dapat dicapai yaitu 100, dengan skor tertinggi yang dicapai adalah 100 dan skor terendah adalah 73 .

Berdasarkan deskripsi pelaksanaan penelitian tindakan kelas siklus II, masalahmasalah yang ada pada fase exploration, fase explanation, dan fase evaluation dalam pemberian tindakan siklus I sudah diperbaiki. Perbaikan-perbaikan yang dilakukan pada pemberian tindakan siklus II dalam tiap fase tersebut ternyata dapat mengatasi masalah-masalah yang muncul pada pemberian tindakan siklus I. Dapat disimpulkan bahwa masalah-masalah tersebut sudah dapat diatasi pada pemberian tindakan siklus II.

Berikut ini merupakan pengkategorian kemampuan menyelesaikan soal cerita koneksi matematik:

a. Indikator 1 (Menuliskan masalah kehidupan sehari-hari dalam bentuk model matematika) kategori sangat kurang, kurang, cukup, baik dan sangat baik berturut-turut adalah 1 orang, 0 orang, 2 orang, 5 orang dan 32 orang.

b. Indikator 2 (Menuliskan konsep matematika yang mendasari jawaban ) kategori sangat kurang, kurang, cukup, baik dan sangat baik berturut-turut adalah 0 orang, 3 orang, 0 orang, 6 orang dan 31 orang.

c. Indikator 3 (Menuliskan hubungan antar obyek dan konsep matematika) kategori sangat kurang, kurang, cukup, baik dan sangat baik berturut-turut adalah 4 orang, 4 orang, 7 orang, 11 orang dan 14 orang.

Banyak siswa yang mengalami peningkatan kemampuan menyelesaikan soal cerita koneksi matematik di hitung dari jumlah pengkategorian cukup, baik, dan sangat baik. Hasil dari siklus II untuk tes kemampuan menyelesaikan soal cerita koneksi matematik sampai akhir siklus I untuk indikator 1, indikator 2, dan indikator 3 , berturut-turut ada sebesar $97,5 \%, 92,5 \%$, dan $80 \%$.

\section{Hasil Analisis Kualitatif}

Keterlaksanaan model pembelajaran Learning Cycle siklus II untuk kegiatan siswa pada pertemuan 1 dan pertemuan 2 berturut-turut presentasinya adalah $90 \%$ 
dan $100 \%$. Berdasarkan hasil presentase dari keterlaksanaan model pembelajaran Learning Cycle $5 E$ untuk kegiatan siswa dapat dikatakan mencapai indikator keberhasilan.

Observasi keterlaksanaan model pembelajaran Learning Cycle siklus II untuk kegiatan siswa pada pertemuan 1 dan pertemuan 2 berturut-turut presentasinya adalah $100 \%$ dan $100 \%$. Berdasarkan hasil presentase dari keterlaksanaan model pembelajaran Learning Cycle 5E untuk kegiatan siswa dapat dikatakan mencapai indikator keberhasilan.

Peningkatan kemampuan menyelesaikan soal cerita koneksi matematik siswa kelas VIII 1 MTs Negeri Model Makassar mengalami peningkatan dari siklus I ke siklus II

\section{Pelaksanaan Tindakan Kelas Siklus I}

Peneliti melakukan pemberian tindakan pada siklus I dengan menggunakan model pebelajaran Learning Cycle "5E". Peneliti memilih model pembelajaran Learning Cycle " $5 \mathrm{E}$ ", karena model pembelajaran Learning Cycle " $5 \mathrm{E}$ " memuat langkahlangkah: engagement, exploration, explanation, elaboration, evaluation. Langkahlangkah tersebut memungkinkan untuk mengembangkan kemampuan menyelesaikan soal cerita koneksi matematik siswa. Masalah-masalah yang ditemui pada pemberian tindakan siklus I adalah pada fase Exploration, fase Explanation, dan fase Evaluation.

Pada fase exploration, sudah dijelaskan sebelumnya terdapat beberapa permasalahan yang siswa hadapi, diantaranya adalah kesulitan siswa dalam menemukan rumus luas permukaan kubus, menyelesaikan soal cerita koneksi matematik yang terdapat pada LKS. Siswa masih kesulitan dalam menuliskan diketahui, ditanyakan, dan membuat model. Siswa juga masih kesulitan dalam menuliskan konsep yang mendasari jawaban, serta siswa masih kesulitan dalam menuliskan hubungan antar obyek dan konsep matematika. Kesulitan-kesulitan ini didiskusikan oleh siswa bersama teman satu kelompok, sehingga siswa mampu mengembangkan pemikirannya dalam wadah diskusi yang ada pada fase exploration model pembelajaran Learning Cycle "5E". Menurut Vygotsky tentang konstruktivisme sosial, yang menyatakan bahwa "Interaksi sosial memainkan peran penting dalam perkembangan intelektual siswa”. Dengan melakukan interaksi sosial yang baik seorang siswa akan terdorong memiliki jiwa kerjasama yang baik jika dibandingkan dengan siswa yang tidak melakukan interaksi sosial teman sebaya. Jiwa kerjasama yang baik dalam disalurkan dalam mengatasi kesulitan belajar, hal ini didasarkan dari penelitian Suharti yang menyimpulkan bahwa interaksi sosial teman sebaya berpengaruh positif terhadap hasil belajar matematika (Suharti, Darwis, \& Anas, 2015).

Fase evaluation, masalah yang ditemui adalah masalah waktu. Tidak cukupnya waktu mengevaluasi pembelajaran pada pertemuan pertama dan kedua menyebabkan fase evaluation kurang maksimal, sehingga waktu siswa untuk 
mengevaluasi hasil pekerjaan siswa juga kurang optimal. Fase evaluation sebenarnya merupakan suatu fase penting. Berdasarkan pendapat Roestiyah (1985: 134), evaluasi merupakan sesuatu yang penting untuk siswa karena dapat menumbuhkan semangat kerja yang lebih baik, dan meningkatkan hasrat belajar. Pendapat tersebut dapat menjelaskan pentingnya evaluasi untuk meningkatkan hasrat belajar siswa, siswa yang mendapat hasil tidak memuaskan terus belajar untuk memperbaiki hasil pekerjaan selanjutnya, sedangkan untuk siswa yang sudah mendapatkan hasil yang memuaskan, siswa terus belajar untuk mempertahankan hasil belajarnya atau bahkan meningkatkan hasil belajarnya pada tes selanjutnya.

Banyak siswa yang mengalami peningkatan kemampuan menyelesaikan soal cerita koneksi matematik dari sebelum pemberian tindakan sampai akhir siklus I untuk indikator 1 (menuliskan masalah kehidupan sehari-hari dalam bentuk model matematik), indikator 2 (menuliskan konsep matematika yang mendasari jawaban), dan indikator 3 (menuliskan hubungan antar obyek dan konsep matematika), berturut-turut ada sebesar 92,5\%, 67,5\%, dan 20\%. Siswa yang mengalami peningkatan kategori untuk indikator 1 (menuliskan masalah kehidupan sehari-hari dalam bentuk model matematik), sudah memenuhi indikator keberhasilan yaitu sudah lebih dari $80 \%$ siswa. Indikator 2 (menuliskan konsep matematika yang mendasari jawaban) dan indikator 3 (menuliskan hubungan antar obyek dan konsep matematika), belum mengalami peningkatan sesuai yang diharapkan sesuai indikator keberhasilan. Peningkatan kategori kemampuan menyelesaikan soal cerita koneksi matematik siswa untuk indikator 2 dan indikator 3 masih kurang dari 80\%.

Indikator 2 dan indikator 3 belum tercapai, besar kemungkinan karena belum adanya petunjuk membuat model matematika pada LKS, guru mengatakan secara lisan untuk siswa membuat model matematika untuk menjawab soal, tetapi tidak tertulis pada LKS. Keberhasilan siswa membuat model matematika, dapat berdampak pada kemampuan siswa menuliskan konsep-konsep yang digunakan siswa dalam menjawab soal (Indikator 2), dan kemampuan siswa untuk menuliskan hubungan antar obyek dan konsep matematika dalam menjawab soal (Indikator 3). Hasil tes kemampuan koneksi matematik siswa pada siklus I belum optimal mungkin dikarenakan masih belum optimalnya fase Exploration, fase Explanation, dan fase

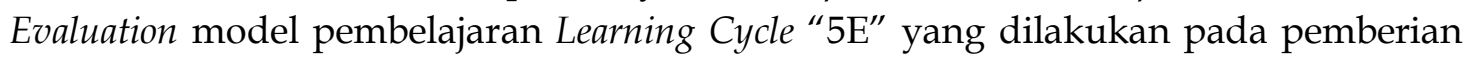
tindakan siklus I. Berdasarkan hasil tes, penelitian akan dilanjutkan ke siklus II dengan perbaikan-perbaikan pada fase Exploration, fase Explanation, dan fase Evaluation model pembelajaran Learning Cycle "5E" agar pemberian tindakan siklus II pada siswa dapat lebih optimal, dan dapat meningkatkan hasil tes kemampuan koneksi matematik siswa di akhir siklus II.

\section{Pelaksanaan Tindakan Siklus II}

Masalah kemampuan menyelesaikan soal cerita koneksi matematik belum teratasi secara optimal. Peningkatan meski sudah ada, namun belum memenuhi indikator keberhasilan pada siklus I. Penelitian dilanjutkan ke siklus II dengan 
pemberian tindakan yang sama seperti pada pemberian tindakan siklus I dengan menggunakan model pembelajaran Learning Cycle " $5 \mathrm{E}$ " dengan langkah-langkah sebagai berikut: engagement, exploration, explanation, elaboration, evaluation. Pemberian tindakan meskipun sama seperti pada pemberian tindakan siklus I, namun adanya perbaikan terutama pada fase exploration dan explanation yang dirasa peneliti masih kurang optimal pada siklus I.

Fase exploration, perbaikan dilakukan pada LKS. Petunjuk pada soal yang tercantum dalam LKS, sudah tertulis jelas membuat model matematika untuk menjawab soal. Petunjuk menjawab soal sudah diperjelas, agar siswa fokus pada petunjuk-petunjuk yang sudah diberikan, sehingga sudah adanya perbaikan hasil pekerjaan siswa pada pertemuaan keempat sampai dengan kelima.

Fase explanation dalam mengatasi siswa yang masih mengobrol, guru mencoba menegur secara verbal, dengan mendekati siswa tersebut. Guru mengatakan bahwa presentasi ini berguna untuk kalian dalam memahami materi pelajaran. Guru mencoba menumbuhkan motivasi siswa tersebut. Guru juga memberikan nasihat agar siswa dapat menghargai orang lain yang sedang berbicara. Menegur seseorang di hadapan umum dengan bersuara keras mengandung resiko, yaitu siswa yang ditegur akan merasa bangga karena mendapat tanggapan positif dari teman sekelas.

Teguran yang diberikan oleh guru ternyata efektif untuk membuat siswa tidak ribut kembali. Pertemuan berikutnya, siswa sudah tidak ribut kembali, siswa fokus dalam memperhatikan presentasi. Siswa aktif, kelas terkondisi dengan baik, presentasi berjalan lancar .

Selanjutnya, banyak siswa yang mengalami peningkatan kemampuan menyelesaikan soal cerita koneksi matematik dari sebelum pemberian tindakan sampai akhir siklus II untuk indikator 1 (menuliskan masalah kehidupan sehari-hari dalam bentuk model matematik), indikator 2 (menuliskan konsep matematika yang mendasari jawaban), dan indikator 3 (menuliskan hubungan antar obyek dan konsep matematika), berturut-turut ada sebesar 97,5\%, 92,5\%, dan 80\%. Peningkatan kemampuan menyelesaikan soal cerita koneksi matematik siswa pada ketiga indikator besar kemungkinan karena perbaikan-perbaikan yang sudah dilakukan pada siklus II, perbaikan pada fase Exploration, fase Explanation, dan pengoptimalan pada fase Evaluation model pembelajaran Learning Cycle " $5 \mathrm{E}^{\text {". }}$

Siswa yang mengalami peningkatan kemampuan menyelesaikan soal cerita koneksi matematik pada ketiga indikator sudah lebih dari 80\%, maka dapat disimpulkan bahwa indikator keberhasilan pada siklus II sudah terpenuhi. Jadi, pemberian tindakan dengan model pembelajaran Learning Cycle " $5 \mathrm{E}$ " dapat meningkatkan kemampuan koneksi matematik siswa kelas VIII MTs Negeri 1 Makassar.

\section{SIMPULAN}

Berdasarkan rumusan masalah dapat ditarik kesimpulan yaitu: (1) keterlaksanaan model pembelajaran dapat dilihat dari lembar observasi kegiatan 
siswa dan kegiatan guru mengalami peningkatan dan mencapai indikator keberhasilan, untuk siklus I dengan dua pertemuan kegiatan siswa berturut-turut yaitu $60 \%$ dan $80 \%$, dan untuk kegiatan guru berturut-turut adalah $80 \%$ dan $90 \%$, serta pada siklus II dengan dua pertemuan untuk kegiatan siswa berturut-turut adalah $90 \%$ dan 100\%, dan kegiatan guru berturut-turut adalah 100\% dan 100\%, (2) Kemampuan menyelesaikan soal cerita koneksi matematik yang berhasil dicapai siswa dengan menggunakan model pembelajaran Learning Cycle pada siklus I untuk indikator 1 (menuliskan masalah kehidupan sehari-hari dalam bentuk model matematik), indikator 2 (menuliskan konsep matematika yang mendasari jawaban), dan indikator 3 (menuliskan hubungan antar obyek dan konsep matematika) berturut-turut ada sebesar $92,5 \%, 67,5 \%$, dan $20 \%$, dan pada siklus II dengan model pembelajaran Learnong Cycle " $5 \mathrm{E}$ ", banyak siswa yang berhasil mengalami peningkatan kemampuan menyelesaikan soal cerita koneksi matematik pada akhir siklus II, untuk indikator 1 (menuliskan masalah kehidupan sehari-hari dalam bentuk model matematik), indikator 2 (menuliskan konsep matematika yang mendasari jawaban), dan indikator 3 (menuliskan hubungan antar obyek dan konsep matematika) berturut-turut ada sebesar $97,5 \%, 92,5 \%$, dan $80 \%$.

\section{DAFTAR PUSTAKA}

Angriani, A. D., Bernard, Nur, R., \& Nurjawahirah. (2016). Meningkatkan Kemampuan Pemecahan Masalah Melalui Pembelajaran Kooperatif Think-Talk-Write Pada Peserta Didik Kelas VIII1 MTs Model Makassar. MaPan: Jurnal Matematika dan Pembelajaran, 4(1), 11-28.

Ermalinda, P. ; (2014). Penelitian Tindakan Kelas. Jakarta: Alfabeta.

Khasana, U. (2015). Kesulitan Menyelesaikan Soal Cerita Matematika Pada Siswa SMP. Surakarta: FKIP Surakarta Universitas Muhammadiyah Surakarta.

Noviantari, P. S.. (2015). Penerapan Model Pembelajaran Learning Cycle "5E"

Berbantuan LKS Terstruktur untuk Meningkatkan Kemampuan Penalaran dan Komunikasi Matematika. Jurnal Santiaji Pendidikan, 5(2), 158-170.

Putra, F. G. (2015). Eksperimentasi Model Pembelajaran Kooperatif Tipe Teams Games Tournament (TGT) Berbantuan Software Cabri 3DDI Tinjau Dari Kemampuan Koneksi Matematis Siswa. Al-Jabar, 6(2), 53-66.

Rahayu, P., Mulyani, S., \& Miswadi, S. S. (2012). Jurnal Pendidikan IPA Indonesia MELALUI LESSON STUDY. Jurnal Pendidikan IPA Indonesia, 1(1), 63-70.

Suharti, Darwis, M., \& Anas, S. (2015). Pengaruh Pola Asuh Demokratis, Interaksi Sosial Teman Sebaya, Kecerdasan Emosional dan Efikasi Diri terhadap Hasil Belajar Matematika Siswa Kelas VIII SMPN Se Kecamatan Manggala di Kota Makassar. Jurnal Daya Matematis, 3(1), 10-19.

Warsono, H. (2014). Pembelajaran Aktif (Teori dan Assesmen). Bandung: Remaja Rosdakarya.

Zaerani, S., Mardhiah, \& Suharti. (2017). Pengaruh Penguasaan Konsep 
Teorema Pythagoras Terhadap Kemampuan Menyelesaikan Soal-Soal Bangun Ruang Sisi Datar pada Siswa Kelas VIII MTs Negeri BalangBalang. MaPan: Jurnal Matematika Dan Pembelajaran, 5(2), 279-292. 